\title{
ISOLASI KHAMIR DARI BATANG TANAMAN TEBU DAN IDENTIFIKASINYA BERDASARKAN SEKUENS INTERNAL TRANSCRIBED SPACER
}

\section{Isolation of Yeasts from Sugarcane Stems and Their Identification Based on Internal Transcribed Spacer Sequences}

\author{
Ika Anggraini ${ }^{\star}$, Rejeki Siti Ferniah, Endang Kusdiyantini \\ Departemen Biologi, Fakultas Sains dan Matematika, Universitas Diponegoro \\ Jl.Prof.H.Soedarto, S.H.Tembalang, Tembalang Kota Semarang, Jawa Tengah 50275 \\ *Email: ikaanggraini71@yahoo.com
}

\begin{abstract}
Fermentative yeasts used in food, health, and energy industries need to be explored to discover their potential. The purpose of this study was to obtain fermentative yeast isolates from sugarcane stems and subsequently to undertake morphological, biochemical, and molecular identification. The isolation of epiphytic and endophytic yeasts was carried out by spread plate method using sugarcane soak water and sugarcane juice on potato dextrose agar (PDA) and yeast-glucose-peptone (YGP) agar media. Morphological identification was based on macroscopic and microscopic observations. Biochemical identification was performed using carbohydrate fermentation and 50\%-glucose media tests. Selected isolates were identified molecularly using Internal Transcribed Spacer (ITS). Seven yeast isolates were obtained, of which isolate Ed $1 B$ was selected. Isolate ED $1 B$ was of round colonies, creamy white colour, shiny, embossed, and wavy appearance, ovoid cell shape with a cell diameter of $4.74 \mu \mathrm{m}$. It had budding cells, was able to ferment glucose and sucrose (but not lactose), and grew on 50 \%-glucose media. Results of BLAST showed that isolates Ed 1B had 99\% homology with Kodamaea ohmeri.
\end{abstract}

Keywords: isolation, ITS, molecular identification, Saccharum officinarum L., yeast

\begin{abstract}
ABSTRAK
Khamir fermentatif yang digunakan dalam industri pangan, kesehatan dan energi perlu dieksplorasi untuk mengetahui potensinya. Tujuan penelitian ini adalah untuk memperoleh isolat khamir fermentatif dari batang tebu dan untuk kemudian diidentifikasi secara morfologi, biokimia dan molekuler. Isolasi khamir epifit dan endofit dilakukan dengan metode cawan sebar dari air rendaman tebu dan jus tebu pada media potato dextrose agar (PDA) dan yeastglucose-peptone (YGP). Identifikasi morfologi berdasarkan pengamatan makroskopis dan mikroskopis. Identifikasi biokimia menggunakan uji fermentasi karbohidrat dan uji media glukosa 50\%. Isolat terpilih diidentifikasi molekuler menggunakan Internal Transcribed Spacer (ITS). Hasil isolasi memperoleh 7 isolat khamir. Satu isolat terpilih (Ed 1B) didapatkan dan memiliki ciri-ciri koloni bulat, putih krem, mengkilap, timbul, bergelombang, bentuk sel ovoid dengan diameter sel 4,74 $\mu \mathrm{m}$, memiliki budding cell, mampu memfermentasi glukosa dan sukrosa, tidak memfermentasi laktosa, serta tumbuh pada media glukosa $50 \%$. Hasil BLAST menunjukkan bahwa isolat Ed 1B memiliki homologi 99\% dengan Kodamaea ohmeri.
\end{abstract}

Kata Kunci: identifikasi molekuler, isolasi, ITS, khamir, Saccharum officinarum L. 


\section{PENDAHULUAN}

Indonesia merupakan negara yang memiliki keanekaragaman hayati yang luas baik di daratan maupun di lautan. Keanekaragaman hayati ini meliputi flora, fauna dan mikroorganisme. Berbagai macam makhluk hidup tersebut mampu beradaptasi dengan baik di Indonesia. Hal ini sesuai dengan pernyataan dari Supriatna (2008), bahwa Indonesia merupakan negara yang tinggi kekayaan keanekaragaman hayatinya. $\mathrm{Hal}$ tersebut dikarenakan Indonesia mempunyai iklim tropis yang menjadi relung berbagai macam flora, fauna, maupun mikroorganisme. Relung kehidupan tersebut banyak tersebar baik di darat maupun di laut.

Keanekaragaman makhluk hidup yang ada di Indonesia salah satunya adalah mikroorganisme, terdiri dari bakteri, virus, jamur dan protozoa. Salah satu jenis mikroorganisme yang melimpah di alam yaitu jamur. Menurut Hidayat et al. (2016), bahwa jamur terbagi menjadi tiga yaitu mushroom (jamur berbadan buah besar), molds (jamur yang berbentuk benang), dan khamir (jamur bersel satu).

Khamir merupakan salah satu mikroorganisme yang banyak digunakan dalam dunia industri karena kemampuannya dalam memfermentasi substrat menjadi produk yang bermanfaat bagi manusia. Kemampuan tersebut banyak diaplikasikan dalam bidang pangan, kesehatan dan energi. Peran fermentasi dalam bidang pangan yaitu Saccharomyces cerevisae untuk pembuatan roti. Peran khamir dalam fermentasi di bidang kesehatan yaitu penghasil xylitol sebagai pengganti gula bagi penderita diabetes. Peran fermentasi dalam bidang energi yaitu kemampuan khamir dalam mengkonversi gula menjadi etanol sebagai sumber energi terbarukan. Hal ini sesuai dengan Rada dan Kaseie (2017), bahwa S. cerevisiae menjadi bahan utama dalam pembuatan roti. Menurut Guo et al. (2006), bahwa genus Candida merupakan jenis khamir penghasil xylitol yang terkenal untuk aplikasi industri. Menurut Testaw dan Assefa (2014), bahwa bahan bakar terbarukan yang paling umum digunakan adalah etanol. Spesies khamir $S$. cerevisae mampu menghasilkan etanol sebagai produk fermentasi utamanya.

Berdasarkan alasan tersebut, maka diperlukan adanya eksplorasi khamir fermentatif. Khamir fermentatif sering dimanfaatkan sebagai agen penghasil etanol dalam industri. Potensi khamir sebagai penghasil etanol di Indonesia sudah cukup banyak diteliti melalui pemanfaatan beberapa substrat alternatif. Namun, secara umum jenis khamir yang dipergunakan masih terbatas pada satu jenis yaitu $S$. cerevisiae atau ragi yang diperjualbelikan di pasar. Eksplorasi khamir fermentatif dilakukan dengan isolasi dan identifikasi. Isolasi khamir dilakukan dengan memisahkan mikroorganisme tertentu dari populasi mikroorganisme lainnya. Khamir fermentatif yang dapat diisolasi dari tanaman tebu mungkin tidak hanya $S$. cerevisiae. Oleh karena itu, melalui penelitian ini diharapkan dapat menambah khasanah pengetahuan masyarakat Indonesia terkait jenis-jenis khamir lokal (Sumerta dan Kanti 2017).

Penelitian khamir ini memiliki metode identifikasi biokimia dan molekuler yang serupa dengan studi dari Suryaningsih et al. (2018), bahwa khamir mampu diisolasi dari jus buah sirsak untuk diidentifikasi secara morfologi, biokimia dan molekuler. Identifikasi biokimia menggunakan uji fermentasi gula dan uji glukosa $50 \%$. Identifikasi molekuler berdasarkan sekuens Internal Transcribed Spacer (ITS). Sekuens ITS dikenal memilki beberapa keunggulan dalam identifikasi khamir secara molekuler. Menurut Ekasari et al. (2012), sekuensing ITS banyak dimanfaatkan untuk analisis sistematis molekular pada tingkat spesies, karena ITS memiliki derajat variasi yang tinggi. Menurut Hidayat et al. (2008) bahwa sekuens ITS memiliki karakteristik unggul yang berukuran kecil (kurang lebih 700 bp). Karakteristik ini menyebabkan sekuens ITS mudah untuk diisolasi, diamplifikasi dan dianalisis. Sekuen ITS mengacu pada spacer yang merupakan sekuen target untuk dilakukannya identifikasi khamir secara molekuler. Berdasarkan uraian tersebut, maka penelitian ini bertujuan untuk melakukan isolasi dan identifikasi khamir fermentatif dari batang tanaman tebu secara molekuler berdasarkan sekuens Internal Transcribed Spacer.

\section{BAHAN DAN METODE}

\section{Waktu dan tempat penelitian}

Penelitian ini dilaksanakan pada Maret 2018 hingga Juni 2018 di Laboratorium Bioteknologi Departemen Biologi Fakultas 
Sains dan Matematika, serta Laboratorium Tropical Marine Biotechnology (TMB) Fakultas Perikanan dan IImu kelautan Universitas Diponegoro, Semarang.

\section{Bahan}

Bahan yang digunakan pada penelitian ini adalah tanaman tebu berwarna hijau yang sehat dan tua dengan umur kurang lebih 8 bulan yang berada di Desa Pelang Kecamatan Mayong Kabupaten Jepara, media Potato Dextrose Agar (PDA), media Yeast Glucose Peptone (YGP), media pertumbuhan glukosa 50\%, media uji fermentasi gula, pewarna Methylen Blue, laktosa, glukosa, sukrosa, etanol $70 \%$, sodium hipoklorit, Phenol red, buffer TBE, DNA ladder marker 100 pb, gel agarosa, chelex, PBS, $\mathrm{dd}_{2} \mathrm{O}$, Promega Kit, Primer ITS 1 dan ITS 4, akuades steril, serta saponin. Jenis tebu yang digunakan dalam penelitian ini adalah tebu hijau.

\section{Isolasi dari jus batang tebu (endofit)}

Tahap awal dalam isolasi khamir dari jus batang tebu adalah sterilisasi permukaan. Sterilisasi permukaan dilakukan dengan cara memilih batang tanaman tebu hijau yang sehat dan tua yang berukuran $50 \mathrm{~cm}$ serta berumur kurang lebih 8 bulan yang dibeli dari pedagang tebu di Desa Pelang Kacamatan Mayong Kabupaten Jepara. Batang tebu dicuci dengan air mengalir untuk menghilangkan tanah liat yang menempel. Batang tebu selanjutnya direndam dalam etanol $70 \%$ dalam 3 menit, dicuci dengan larutan sodium hipoklorit segar selama 5 menit, dibilas dengan etanol $70 \%$ selama 30 detik dan akhirnya dicuci lima kali dengan akuades steril. Batang tebu selanjutnya dikeringkan di atas tissue steril (Tam dan Diep 2014). Tahap selanjutnya adalah pembuatan perlakuan kontrol negatif. Kontrol negatif bertujuan sebagai parameter keberhasilan proses sterilisasi permukaan. Keberhasilan sterilisasi permukaan ditandai dengan tidak adanya pertumbuhan mikroorganisme pada media kontrol. Perlakuan kontrol negatif dilakukan dengan cara mengisolasi khamir dari aquades bilasan terakhir hasil tahap sterilisasi permukaan. Akuades tersebut kemudian diambil sebanyak $50 \mu \mathrm{L}$ dan diinokulasikan ke media PDA/YGP pada cawan petri. Media selanjutnya diinkubasi pada suhu ruang selama 48 jam (Intan et al. 2014).
Langkah berikutnya adalah pembuatan jus batang tebu. Batang tebu sebanyak $150 \mathrm{~g}$ dikupas dan diiris dengan pisau steril, kemudian diblender dengan $200 \mathrm{~mL}$ air. Larutan tebu tersebut selanjutnya disaring menggunakan penyaring steril ke dalam botol steril dalam kondisi aseptik. Sampel larutan batang tebu kemudian disimpan selama 48 jam pada suhu kamar (Obasi et al. 2014).

Jus tebu yang sudah tersedia selanjutnya digunakan untuk isolasi khamir. Jus tebu yang telah disimpan selama 48 jam, diambil sebanyak $1 \mathrm{~mL}$ dilakukan seri pengenceran hingga $10^{-5}$ dan $10^{-6}$ menggunakan akuades steril. Isolasi khamir dilakukan dengan mengambil sebanyak 0,5 $\mathrm{mL}$ larutan dari pengenceran tersebut dan dilakukan dengan metode cawan sebar pada media PDA/YGP dalam keadaan aseptis. Media PDAYGP telah ditambah kloramfenikol untuk mencegah tumbuhnya bakteri. Media tersebut lalu diinkubasi pada suhu ruang selama 48 jam, kemudian isolat yang terpisah (koloni tunggal) dimurnikan dengan cara digores kembali pada media agar miring di tabung reaksi (Okwulehie et al. 2010).

Isolasi dari air rendaman batang tebu (epifit) Isolasi khamir epifit dilakukan dari batang tebu yang sehat dan tua dengan umur kurang lebih 8 bulan, kemudian batang tebu dengan kondisi tanpa dikupas kulitnya dipotong kecil-kecil menggunakan pisau steril. Potongan batang tebu sebanyak $15 \mathrm{~g}$ dimasukkan ke dalam $150 \mathrm{~mL}$ aquades steril, kemudian digojok menggunakan rotary shaker dengan kecepatan 120 rpm selama 24 jam. Air rendaman tebu selanjutnya diencerkan hingga pengenceran $10^{-5}$ dan $10^{-6}$ lalu diambil suspensi sebanyak $0,5 \mathrm{~mL}$ dan diinokulasikan pada media PDA/YGP dengan metode cawan sebar. Media PDA/YGP telah ditambah dengan kloramfenikol untuk mencegah tumbuhnya bakteri. Khamir yang tumbuh kemudian dimurnikan dengan cara digoreskan pada media PDA/YGP miring dan diinkubasi pada suhu ruang selama 48 jam untuk selanjutnya diidentifikasi (Intan et al. 2014).

\section{Identifikasi morfologi}

Isolat sebanyak 1 ose ditambahkan dengan 1 tetes Methylen blue dan diamati di bawah mikroskop perbesaran 1000x (Widiastutik dan Alami 2014). 


\section{Identifikasi biokimia}

Identifikasi biokimia yang dilakukan pada penelitian ini adalah uji fermentasi karbohidrat dan uji pertumbuhan konsentrasi glukosa $50 \%$.

\section{Uji fermentasi karbohidrat}

Uji fermentasi dilakukan pada tabung Durham. Gula yang digunakan adalah glukosa, sukrosa, dan laktosa. Media untuk uji fermentasi karbohidrat dimasukkan ke dalam tabung reaksi sebanyak $5 \mathrm{~mL}$. Isolat khamir sebanyak 1 ose dari media padat yang telah berumur 48 jam diambil lalu diinokulasikan ke dalam media uji fermentasi. Setelah itu dilakukan inkubasi selama 7 hari pada suhu ruang $\pm 28^{\circ} \mathrm{C}$ (Sari et al. 2016). Khamir yang melakukan fermentasi dapat menghasilkan gelembung, dinyatakan tanda (+). Apabila tidak menghasilkan gelembung, maka khamir dinilai tidak mampu melakukan fermentasi yang dinyatakan dengan tanda (-) (Rahmansyah dan Kanti 1999). Uji fermentasi yang positif ditandai dengan terjadinya perubahan warna media menjadi kekuningan (Widiastutik dan Alami 2014).

\section{Uji pertumbuhan pada media glukosa $\mathbf{5 0} \%$}

Uji ini bertujuan untuk mengetahui apakah khamir bersifat toleran terhadap tekanan osmosis tinggi (osmotoleran). Kultur isolat khamir umur 48 jam diinokulasikan pada media pertumbuhan yang mengandung $50 \%$ glukosa dengan cara goresan di dalam cawan petri, diinkubasikan pada suhu kamar selama 72 jam dan diamati untuk pertumbuhannya (Jimoh et al. 2012).

\section{Seleksi isolat terpilih}

Seleksi isolat terpilin dilakukan sebelum tahap identifikasi molekuler. Isolat terpilih yang diidentifikasi secara molekuler berjumlah 1 isolat. Syarat terpilihnya isolat diantaranya yaitu isolat memiliki durasi waktu paling cepat dalam memfermentasi karbohidrat, paling banyak jenis karbohidrat yang berhasil terfermentasi, serta paling cepat tumbuh pada media glukosa $50 \%$.

\section{Isolasi DNA khamir}

Isolasi DNA dilakukan dengan menggunakan metode chelex. Metode ini dilakukan dengan cara, 3 ose kultur khamir umur 48 jam diinokulasikan ke dalam tube yang telah diberi $100 \mu \mathrm{L} d d \mathrm{H}_{2} \mathrm{O}$, kemudian ditambahkan saponin $0,5 \%$ dalam phosphate buffer saline (PBS) sebanyak 1 $\mathrm{mL}$. Sampel diinkubasi pada suhu $4^{\circ} \mathrm{C}$ selama 24 jam (overnight). Sampel selanjutnya disentrifugasi pada kecepatan $12.000 \mathrm{rpm}$ selama 10 menit. Tahapan sentrifuge akan menyebabkan terbentuknya lapisan natan dan supernatan. Lapisan supernatan kemudian dibuang dengan mikropipet untuk menghilangkan saponin tanpa merusak pelet. Proses ini dilakukan dengan hati-hati dan dipastikan pelet DNA masih melekat pada dasar tabung. Langkah selanjutnya yaitu dengan menambahkan PBS $1 \times$ sebanyak $1 \mathrm{~mL}$ pada sampel. Sampel kemudian disentrifugasi pada kecepatan 12.000 rpm selama 5 menit. Supernatan yang terbentuk di bagian atas dibuang dengan menggunakan mikropipet. Sampel kemudian ditambahkan $\mathrm{ddH}_{2} \mathrm{O}$ sebanyak $100 \mu \mathrm{L}$ dan $20 \%$ larutan Chelex sebanyak $50 \mu \mathrm{L}$. Sampel kemudian dididihkan pada air mendidih selama 5 menit, lalu dihomogenkan dengan vortex sekitar 15-30 detik. Sampel lalu dididihkan kembali selama 5 menit, dan dihomogenkan dengan vortex lagi sekitar 15-30 detik. Langkah terakhir yaitu sampel disentrifugasi pada kecepatan $12.000 \mathrm{rpm}$ selama 10 menit. Supernatan (cairan yang terdapat pada bagian atas) diambil dengan menggunakan mikropipet dan dipisahkan dari pelet (endapan). Supernatan yang mengandung genom DNA kemudian dipindahkan pada mikrotube bersih. Sampel kemudian langsung digunakan untuk proses amplifikasi DNA dan elektroforesis (Santoso et al. 2015)

\section{Pengecekan konsentrasi dan kemurnian DNA}

Konsentrasi dan kemurnian sampel DNA diukur menggunakan Nanodrop 2000 sebanyak $1 \mu \mathrm{L}$ (Purnamasari et al. 2012). Sampel DNA dicek kemurnian dan konsentrasinya pada rasio panjang gelombang 260/280 1,8 untuk DNA dan rasio 260/280 2,0 untuk RNA (Desjardins dan Conklin 2010).

\section{Amplifikasi DNA}

Teknik dari Polymerase Chain Reaction (PCR) digunakan untuk amplifikasi DNA khamir. Amplifikasi daerah ITS rDNA dilakukan dengan pembuatan PCR mix 
dengan volume $50 \mu \mathrm{L}$ yang terdiri dari PCR kit merk promega $25 \mu \mathrm{L}, \mathrm{ddH}_{2} \mathrm{O} 12 \mu \mathrm{L}$, Primer forward (ITS1) dengan konsentrasi 10 $\mathrm{pmol} / \mu \mathrm{L}$ sebanyak $4 \mu \mathrm{L}$, Primer reverse (ITS4) dengan konsentrasi $10 \mathrm{pmol} / \mu \mathrm{L}$ sebanyak $4 \mu \mathrm{L}$, dan sample sebanyak $5 \mu \mathrm{L}$. Amplifikasi DNA dilakukan sebanyak 35 siklus dengan tahapan yaitu pre denaturasi

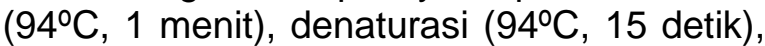
annealing $\left(55^{\circ} \mathrm{C}, 15\right.$ detik), Extension $\left(72^{\circ} \mathrm{C}\right.$, 10 detik), post extension $\left(72^{\circ} \mathrm{C}, 5\right.$ menit) dengan suhu $4^{\circ} \mathrm{C}$. Primer yang digunakan pada penelitian ini adalah primer ITS 1 (5' TCC GTA GGT GAA CCT GCGG 3') dan ITS4 (5'TCC TCC GCT TAT TGA TATGC 3').

\section{Elektroforesis}

Proses PCR yang telah selesai selanjutnya dilakukan elektroforesis untuk mengetahui panjang pita DNA target yang diinginkan. Elektroforesis dilakukan dengan cara gel agarosa $1 \%$ yang terdiri dari $0,3 \mathrm{~g}$ agarosa dilarutkan dalam $30 \mathrm{~mL}$ buffer TBE $1 \times$. Komponen elektroforesis yang digunakan

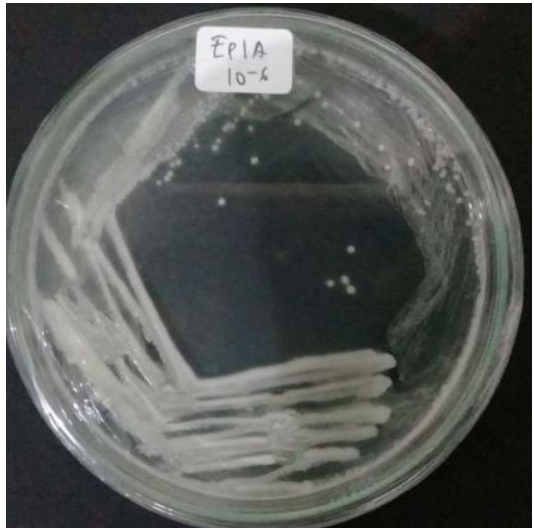

(a)

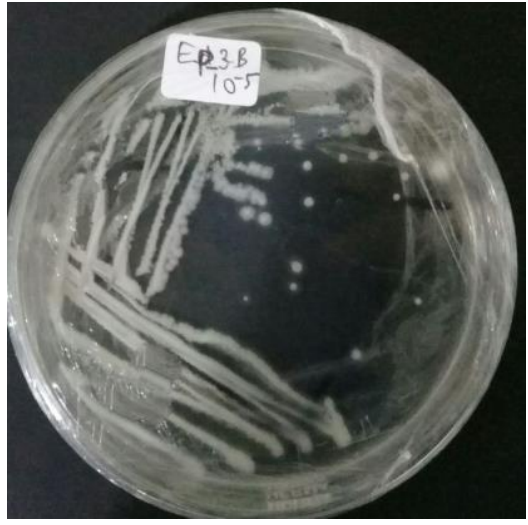

(d)

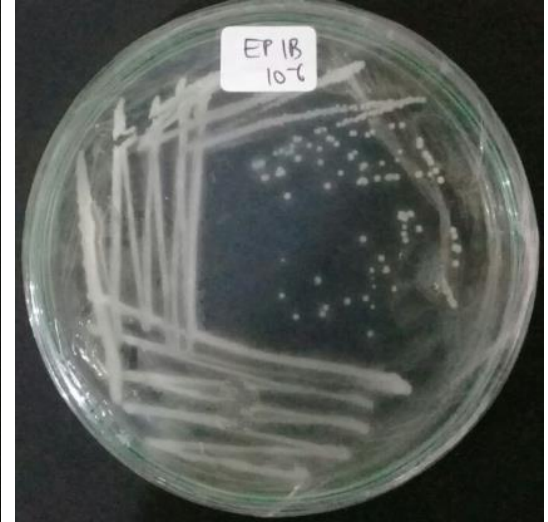

(b)

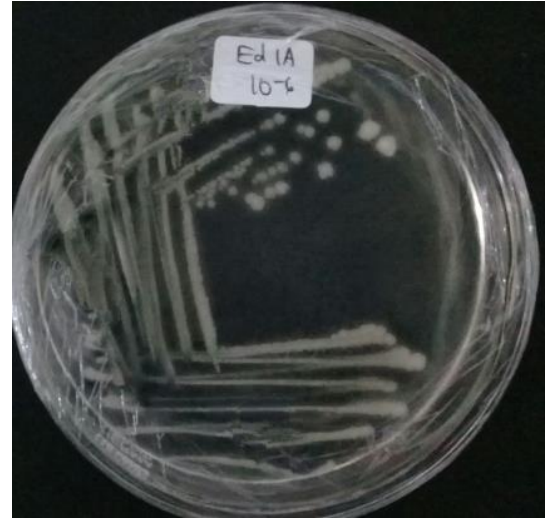

(e)

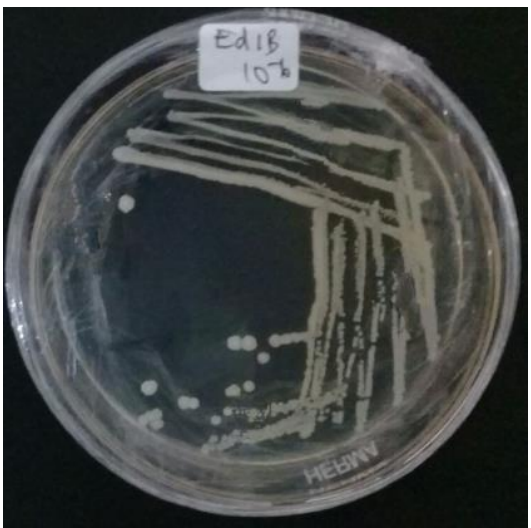

(g)

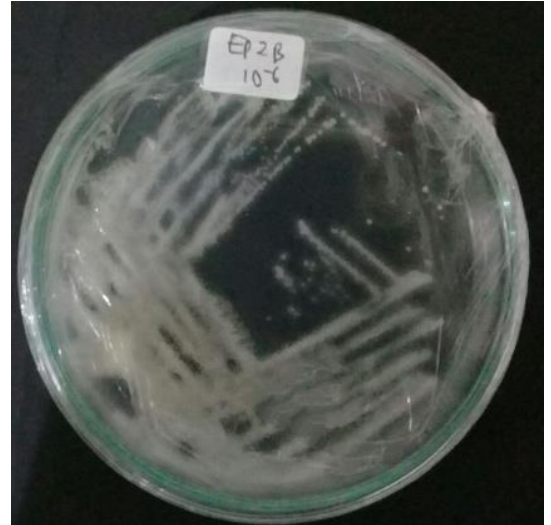

(c)

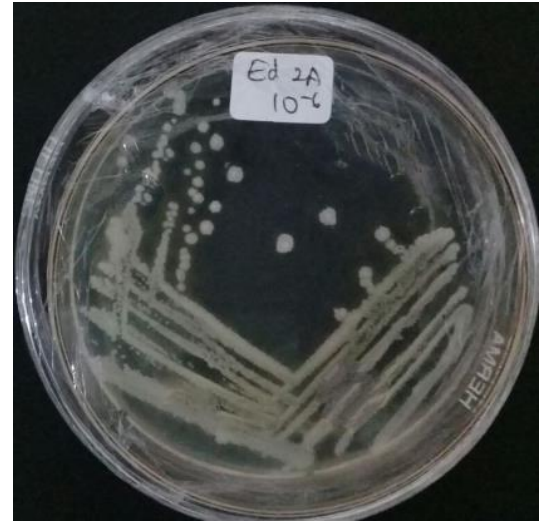

(f) diisolasi dari batang tanaman tebu pada media YGP dan kloramfenikol dengan waktu inkubasi 48 jam 
meliputi $5 \mu \mathrm{L}$ produk PCR dan $3 \mu \mathrm{L}$ ladder marker 100 pb dimasukkan ke dalam sumuran gel agarose $1 \%$ yang telah direndam larutan buffer TBE 1x. Elektroforesis kemudian dilakukan dengan tegangan 100 volt selama 30 menit. DNA akan bermigrasi dari kutub negatif ke kutub positif. Gel selanjutnya direndam dalam etidium bromida selama 15 menit dan dibilas dengan akuades steril selama 3 menit. Gel kemudian diambil dan dimasukkan dalam $\mathrm{Gel}$ doc. Hasil band-band DNA akan terlihat berpendar pada layar gel documentation.

\section{Analisis sequencing}

Produk PCR disekuensing untuk mengetahui jumlah dan urutan basanya melalui jasa PT. Genetika Science Indonesia.

\section{Pohon filogenetik}

Pembuatan pohon filogenetik dilakukan menggunakan software MEGA6. Pohon filogenetik kemudian direkonstruksi menggunakan Neighbour joining dan diuji dengan menggunakan Bootstrap method (Sumerta dan Kanti 2017). Neighbor-Joining adalah metode berbasis jarak yang memiliki keakuratan dan kecepatan, sehingga diterima oleh komunitas filogeni (Elias dan Lagergren 2009). Bootstrap method adalah pendekatan komputasi yang terkenal dalam penilaian pohon filogenetik, dan lebih umum menilai kepercayaan model statistik (Ren et al. 2013).

\section{HASIL DAN PEMBAHASAN}

Hasil isolasi khamir diperoleh 7 isolat yaitu, isolat $\mathrm{Ep} 1 \mathrm{~A}, \mathrm{Ep} 1 \mathrm{~B}, \mathrm{Ep} 2 \mathrm{~B}$, Ep 3B, Ed 1A, Ed 2A, dan Ed 1B. Isolatisolat tersebut terdiri dari khamir epifit dan khamir endofit yang keduanya dikulturkan pada media Potato Dextrose Agar dan media Yeast Glucose Peptone. Karakter makroskopis isolat khamir yang diisolasi dari batang tanaman tebu di antaranya yaitu ketujuh isolat memiliki bentuk koloni bulat, warna isolat beragam yaitu Ep $1 \mathrm{~A}$ dan Ep 2B berwarna putih susu, isolat Ep 3B berwarna putih kecoklatan, dan isolat Ep 1B, Ed 1A, Ed 2A, Ed 1B berwarna putih krem. Elevasi semua koloni timbul, permukaan semua koloni mengkilap, tepian koloni beragam yaitu tepi koloni Ep
1A dan Ep 2B rata, tepi koloni Ep 1B berombak, sedangkan tepi koloni Ep 3B, Ed 1A, Ed 2A, dan Ed 1B bergelombang (Gambar 1). Menurut Kurtzman dan Fell (2011), bahwa warna koloni khamir yang bervariasi seperti kuning, oranye dan merah. Mayoritas khamir berwarna dari putih hingga krem. Permukaan koloni khamir di antaranya yaitu berkilau atau kusam, halus, kasar, sektor, terlipat, bergerigi, atau berbulu. Elevasi koloni khamir diantaranya yaitu datar, tertekan di tengah, menonjol dan seperti kubah, atau berbentuk kerucut. Tepian koloni khamir di antaranya yaitu bergelombang, melengkung, erose, atau dibatasi oleh hifa.

Karakter mikroskopis dari ketujuh isolat khamir menunjukkan bahwa semua isolat memiliki bentuk sel ovoid, morfologi aseksual berupa budding, dan memiliki ukuran sel berdiameter antara 3-4 $\mu \mathrm{m}$ (Gambar 2). Menurut Kurtzman dan Fell (2011), bahwa reproduksi aseksual yang terjadi pada khamir di antaranya yaitu budding (tunas), fusi dan produksi ballistoconidia. Sel khamir dapat berbentuk bulat, subglobose, ellipsoid, ovoid, obovoid, silindris, botuliform, bacilliform, elongate, apiculate, ogival, luning, atau segitiga. Menurut Afshan et al. (2017), bahwa diameter khamir berkisar antara 3-4 $\mu \mathrm{m}$.

Sel khamir hidup dapat berwarna transparan karena methylen blue tidak dapat menembus membran sel, sedangkan sel khamir yang mati berwarna biru karena methylen blue dapat menembus membran sel. Menurut Boyd et al. (2003), bahwa sel hidup mampu mereduksi pewarna, sehingga hanya sel mati yang berwarna biru.

Berdasarkan hasil uji fermentasi karbohidrat, ketujuh isolat menunjukkan perubahan warna dan adanya gelembung pada media glukosa dan sukrosa saat umur biakan 24-168 jam. Perubahan warna tersebut terjadi saat warna media merah yang berubah menjadi warna kuning dan munculnya gelembung pada tabung Durham. Tetapi perubahan tersebut tidak berlaku pada media yang mengandung laktosa. Hal ini disebabkan khamir tersebut tidak mampu memfermentasi laktosa, namun mampu memfermentasi glukosa dan sukrosa. 


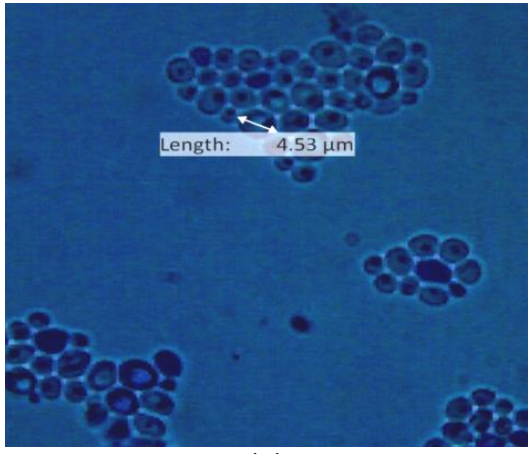

(a)

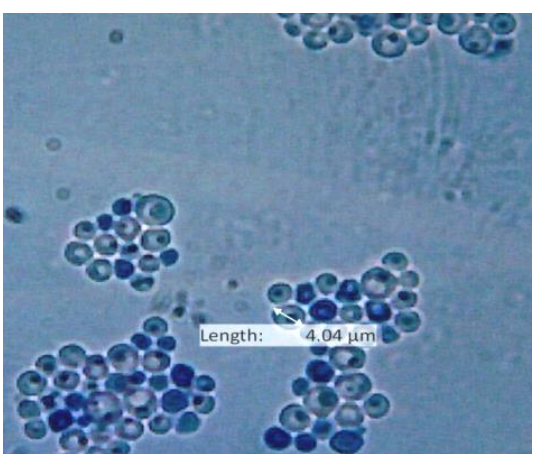

(d)

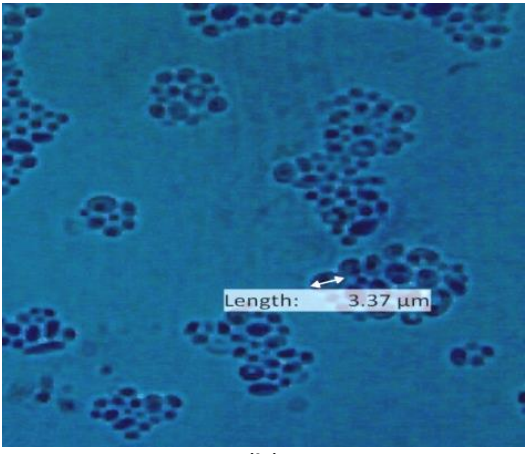

(b)

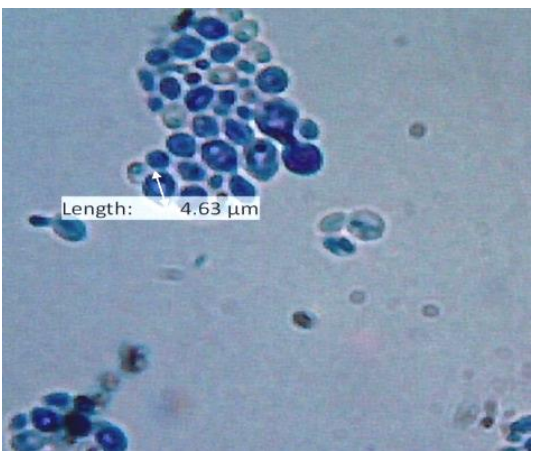

(e)

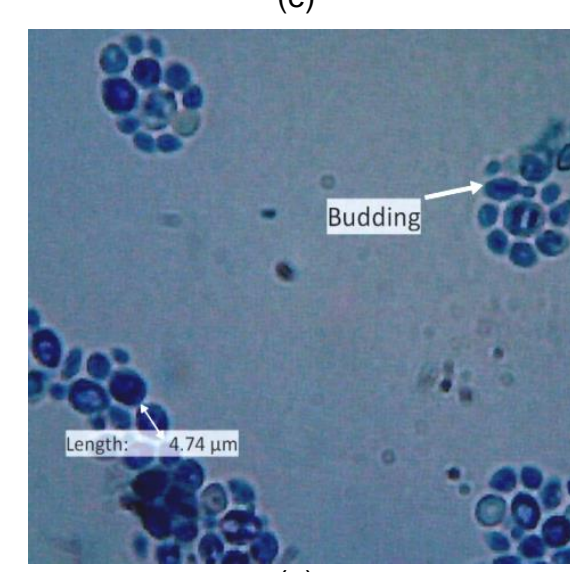

(g)

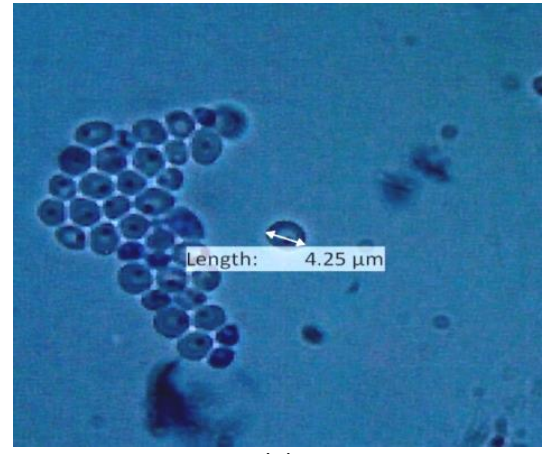

(c)

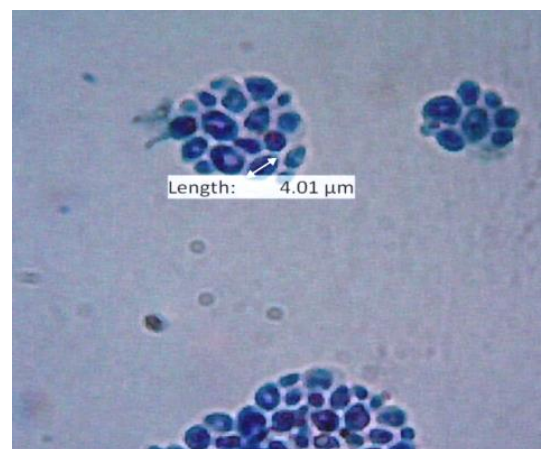

(f)

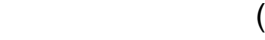

Gambar 2. Morfologi sel isolat (a) Ep 1A, (b) Ep 1B, (c) Ep 2B, (d) Ep 3B, (e) Ed 1A, (f) Ed 2A, dan (g) Ed 1B yang berumur 48 jam pada perbesaran mikroskop 1000× menggunakan pewarna methylene blue

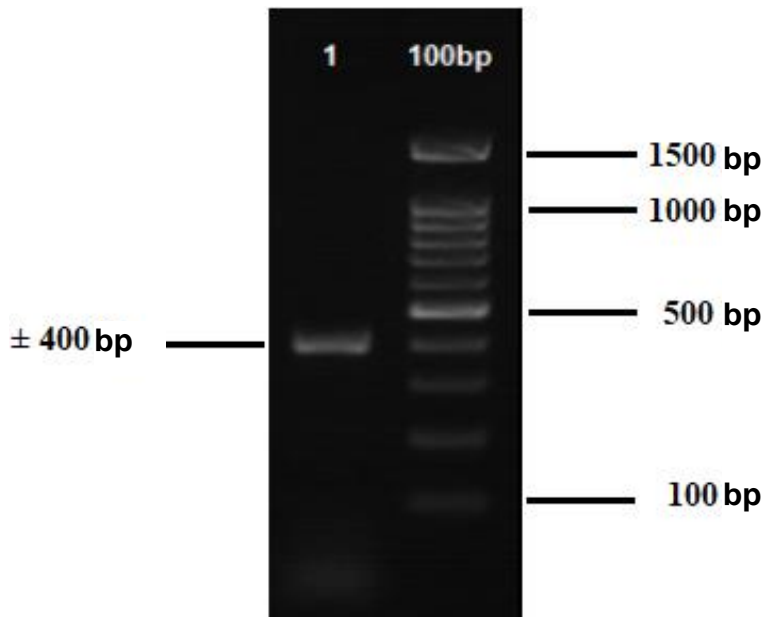

Gambar 3. Hasil sekuensing isolat Ed 1B ( \pm 400 bp)
Ketujuh isolat khamir menunjukkan kemampuan kuat dalam memfermentasi glukosa dan sukrosa selama 7 hari (168 jam). Menurut Giri dan Kindo (2015), bahwa produksi gas dalam tabung itu dianggap sebagai hasil positif dalam memfementasi gula sementara jika hanya produksi asam dianggap sebagai kemampuan dalam asimilasi karbohidrat. Menurut Kurtzman dan Fell (2011), jika dihasilkannya gas pada tabung Durham selama 7 hari, maka reaksi tersebut dianggap sebagai reaksi positif yang kuat.

Berdasarkan pengamatan selama 3 hari pada suhu ruang, dapat disimpulkan bahwa isolat mampu hidup dan tumbuh 
Tabel 1. Hasil identifikasi morfologi isolat khamir

\begin{tabular}{|c|c|c|c|c|c|c|c|c|c|}
\hline \multirow{2}{*}{ Isolat } & \multirow{2}{*}{ Endofit } & \multirow{2}{*}{ Epifit } & \multicolumn{5}{|c|}{ Karakteristik makroskopis } & \multicolumn{2}{|c|}{ Karakteristik mikroskopis } \\
\hline & & & Bentuk & Warna & Elevasi & Permukaan & Tepian & $\begin{array}{c}\text { Bentuk } \\
\text { sel }\end{array}$ & $\begin{array}{c}\text { Reproduksi } \\
\text { aseksual }\end{array}$ \\
\hline Ep 1A & & $\sqrt{ }$ & bulat & putih susu & timbul & mengkilap & rata & ovoid & budding cell \\
\hline Ep 1B & & $\sqrt{ }$ & bulat & putih krem & timbul & mengkilap & berombak & ovoid & budding cell \\
\hline Ep 2B & & $\sqrt{ }$ & bulat & putih susu & timbul & mengkilap & rata & ovoid & budding cell \\
\hline Ep 3B & & $\sqrt{ }$ & bulat & putih kecoklatan & timbul & mengkilap & bergelombang & ovoid & budding cell \\
\hline $\mathrm{Ed} 1 \mathrm{~A}$ & $\sqrt{ }$ & & bulat & putih krem & timbul & mengkilap & bergelombang & ovoid & budding cell \\
\hline $\mathrm{Ed} 2 \mathrm{~A}$ & $\sqrt{ }$ & & bulat & putih krem & timbul & mengkilap & bergelombang & ovoid & budding cell \\
\hline Ed 1B & $\sqrt{ }$ & & bulat & putih krem & timbul & mengkilap & bergelombang & ovoid & budding cell \\
\hline
\end{tabular}

Keterangan:

$\sqrt{ }:$ Jenis khamir berdasarkan asalnya

Tabel 2. Hasil identifikasi biokimia isolat khamir

\begin{tabular}{|c|c|c|c|c|}
\hline \multirow{2}{*}{ Isolat } & \multicolumn{3}{|c|}{ Uji fermentasi karbohidrat } & \multirow{2}{*}{ Uji glukosa $50 \%$} \\
\hline & Glukosa & Sukrosa & Laktosa & \\
\hline Ep 1A & + & + & - & + \\
\hline Ep 1B & + & + & - & + \\
\hline Ep 2B & + & + & - & + \\
\hline Ep 3B & + & + & - & + \\
\hline Ed $1 \mathrm{~A}$ & + & + & - & + \\
\hline $\mathrm{Ed} 2 \mathrm{~A}$ & + & + & - & + \\
\hline Ed 1B & + & + & - & + \\
\hline
\end{tabular}

Keterangan

+ : Hasil uji positif

- : Hasil uji negatif

pada media dengan kadar glukosa $50 \%$. Menurut Lasmini (2016), bahwa khamir yang mampu hidup pada media glukosa $50 \%$ tersebut bersifat toleran terhadap tekanan osmosis tinggi (osmotoleran). Menurut Bubnova et al. (2014), bahwa osmotoleran adalah kemampuan untuk bertahan hidup pada lingkungan dengan tekanan osmotik tinggi. Hasil identifikasi morfologi dan biokimia khamir dapat dilihat pada Tabel 1 dan Tabel 2.

Berdasarkan hasil perbandingan kemampuan dari ketujuh isolat, maka didapatkan satu isolat terpilih yaitu isolat $\mathrm{Ed}$ 1B. Isolat tersebut digunakan sebagai isolat terpilih karena menghasilkan gelembung pada media glukosa dan sukrosa dengan waktu 24 jam, serta tumbuh cepat pada media glukosa $50 \%$. Isolat Ed $1 \mathrm{~B}$ selanjutnya diidentifikasi secara molekuler dengan sekuens Internal Transcribed Spacer (ITS). Identifikasi molekuler pada isolat $\mathrm{Ed} 1 \mathrm{~B}$ diawali dengan melakukan ekstraksi DNA dengan metode chelex. Kemurnian dan konsentrasi DNA pada isolat $\mathrm{Ed} 1 \mathrm{~B}$ diukur dengan menggunakan Nanodrop 2000 pada panjang gelombang $260 \mathrm{~nm}$ dan $280 \mathrm{~nm}$, sehingga didapatkan hasil bahwa konsentrasinya sebesar 182,7 ng/ $\mu \mathrm{L}$ dan kemurniannya sebesar 1,70. Menurut Isci et al. (2014), bahwa nilai kemurnian DNA berkisar pada 1,8-2,0. Jika rasio lebih dari 2,0 menunjukkan adanya kontaminasi RNA, namun bila rasio dibawah 1,8 menunjukkan adanya kontaminasi protein. Menurut Hikmatyar et al. (2015), bahwa DNA berkualitas baik berdasarkan uji Nanodrop memiliki konsentrasi di atas $100 \mathrm{ng} / \mu \mathrm{L}$.

Panjang pita DNA isolat Ed $1 \mathrm{~B}$ adalah \pm 400 bp (Gambar 3). Berdasarkan panjang 
Tabel 3. Urutan nukleotida hasil contig forward ITS1 dan reverse ITS4

TGATCCTTCCGTAGGGTGAACCTGCGGAAGGATCATTAACATAATATTCTTACACACTGTTTTTTTACAACAAAACAAATCTATCT AAAAACAATTCTTTACAAGAAATTCTTAAAACTTTCAACAACGGATCTCTTGGTTCTCGCATCGATGAAGAACGCAGCGAAATGCG ATACGTAATACGAATCGCAGCTCTCGGAATCATCGAATCTTTGAACGCACATTGCACCATTGGGTATTCCCAATGGTATGCTTGTT TGAGCGAATACTTCCCTAATCCTCACGGATTGTATTGTGTTTGCACGAAAATAATGACGACAGTACTCTACAAAACGGTACCGTCA GTACACTCATTTTTTTCCTCAAATCAAGTAGGACTACCCGCTGAACTTAAGCATATCAATAAGCCGGAGGAAA

Tabel 4. Hasil analisis homologi menggunakan BLAST (Basic Local Alignment Search Tools)

\begin{tabular}{|c|c|c|c|c|c|c|}
\hline Jescription & $\begin{array}{l}\text { Max } \\
\text { score }\end{array}$ & Total score & Query cover & E value & Ident & Accession number \\
\hline $\begin{array}{l}\text { Kodamaea ohmeri } \\
\text { JBS } 5367\end{array}$ & 717 & 717 & $100 \%$ & 0.0 & $99 \%$ & NR_121464.1 \\
\hline $\begin{array}{l}\text { Kodamaea nitidulidarum } \\
\text { JBS } 8491\end{array}$ & 468 & 468 & $100 \%$ & $3 e-129$ & $88 \%$ & NR_155241.1 \\
\hline $\begin{array}{l}\text { Kodamaea kakaduensis } \\
\text { IBS } 8611\end{array}$ & 460 & 460 & $100 \%$ & $5 e-127$ & $87 \%$ & NR_155240.1 \\
\hline $\begin{array}{l}\text { Kodamaea transpacifica } \\
\text { ILQCA-24i-070 }\end{array}$ & 442 & 442 & $96 \%$ & $2 e-121$ & $88 \%$ & KF002564.1 \\
\hline $\begin{array}{l}\text { Kodamaea anthophila } \\
\text { こBS } 8494\end{array}$ & 429 & 429 & $100 \%$ & $2 e-117$ & $86 \%$ & NR_155239.1 \\
\hline $\begin{array}{l}\text { Saccharomyces cerevisiae } \\
\text { JBS } 1171\end{array}$ & 185 & 185 & $37 \%$ & $7 e-49$ & $89 \%$ & NR_111007.1 \\
\hline
\end{tabular}
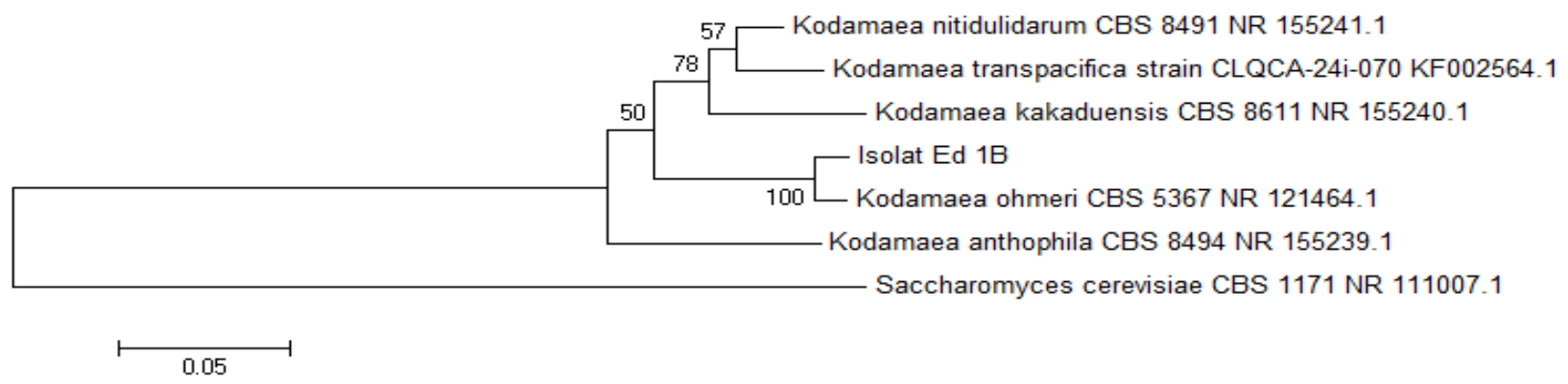

Gambar 4. Pohon filogenetik dengan menggunakan neighbor-joining dengan uji bootstrap 1000.

pita tersebut, maka dapat diketahui bahwa isolat $\mathrm{Ed} 1 \mathrm{~B}$ merupakan khamir karena memiliki panjang pita DNA >380 bp. Menurut Korabecna (2003), bahwa hasil amplifikasi fragmen daerah ITS khamir menggunakan primer ITS1 dan ITS4 memiliki ukuran sekitar 380 hingga 900 bp. Hasil analisis program MEGA 6 merupakan urutan nukleotida hasil contig forward ITS1 dan reverse ITS4 (Tabel 3). Hasil analisis BLAST ditunjukkan pada Tabel 4.

Sequence from type material digunakan dalam taksonomi karena mempunyai tingkat kepercayaan yang tinggi. Isolat Ed 1B memiliki kesamaan sequence hingga $99 \%$ dengan species Kodamaea ohmeri. Hal ini menunjukkan bahwa isolat $\mathrm{Ed}$
1B merupakan anggota dari spesies $K$. ohmeri. Menurut Federhen (2014), bahwa Sequence from type material adalah bagian penting dari GenBank yang mana dapat memiliki tingkat kepercayaan yang sangat tinggi dalam identifikasi taksonomi. Menurut Stamps et al. (2012), bahwa sequence dibandingkan dengan database publik menggunakan software (perangkat lunak) nukleotida yaitu software BLAST. Strain khamir dengan sequence identity $99 \%$ atau lebih tinggi dari itu, maka dianggap sebagai spesies yang sama.

Isolat Ed 1B memiliki nilai boostrap 100 dengan species $K$. ohmeri CBS 5367. Hal ini menunjukkan bahwa isolat $\mathrm{Ed} 1 \mathrm{~B}$ memiliki hubungan kekerabatan yang sangat dekat 
Tabel 5. Perbandingan morfologi dan biokimia Isolat Ed 1B dengan Kodamaea ohmeri (Pichia ohmeri)

\begin{tabular}{lcc}
\hline Karakter & Isolat Ed 1B & Kodamaea ohmeri (Pichia ohmeri) \\
\hline Bentuk koloni & bulat & bulat (Sharma et al. 2018) \\
Warna koloni & putih krem & putih (Kurtzman dan Fell 1998) \\
Elevasi koloni & timbul & timbul (Sharma et al. 2018) \\
Permukaan koloni & mengkilap & buram (Sharma et al. 2018) \\
Tepian koloni & bergelombang & regular (Sharma et al. 2018) \\
Bentuk sel & ovoid & ovoid (Sharma et al. 2018) \\
Diameter sel & $4,47 \mu m$ & tidak dijelaskan dalam referensi \\
Reproduksi aseksual & budding & budding (Sharma et al. 2018) \\
Fermentasi glukosa & + & + (Kurtzman dan Fell 1998) \\
Fermentasi sukrosa & + & + (Kurtzman dan Fel 1998) \\
Fermentasi laktosa & - & - (Mycobank 2018) \\
Pertumbuhan pada konsentrasi glukosa 50\% & + & + (Mycobank 2018) \\
\hline
\end{tabular}

Keterangan

+ : Hasil uji positif

- : Hasil uji negatif

dengan K. ohmeri CBS 5367. Nilai boostrap 100 menunjukkan bahwa dalam 1000 kali ulangan, terbentuk 1000 pohon yang sama. Menurut Dharmayanti (2011), bahwa analisis boostrap adalah metode yang menguji seberapa baik set data model. Nilai boostrap ditunjukkan pada angka yang terletak pada cabang-cabang pohon filogenetika. Jika nilai boostrap rendah maka sekuen seharusnya dikeluarkan dari analisis untuk mendapatkan sebuah pohon filogenetika yang dapat dipercaya. Menurut Lamey et al. (2009), bahwa cabang kelompok yang didukung lebih dari $70 \%$ atau $75 \%$, maka dapat dipercaya. Pohon filogenetik pada isolat $\mathrm{Ed} 1 \mathrm{~B}$ ditunjukkan Gambar 4.

Isolat khamir Ed 1B memiliki kemiripan dengan species $K$. ohmeri terletak pada morfologi isolat dan fisiologisnya pada uji biokimia. K. ohmeri merupakan nama lain dari Pichia ohmeri. Menurut Sharma et al. (2018) genus Kodamaea sebelumnya ditempatkan di bawah genus Pichia tetapi kemudian dipisahkan karena pertimbangan jarak genetiknya berdasarkan sekuens RNA ribosomal $18 \mathrm{~S}$ dan $26 \mathrm{~S}$ dan hanya tujuh spesies yang ditempatkan di bawah genus Kodamaea yaitu $K$. anthophila, K. kakaduensis, K. ohmeri, K. laetipori, K. nitidulidarum, $K . \quad$ transpacifica, $K$. meredithae. Menurut studi dari Yamada et al. (1995), bahwa $K$. ohmeri secara filogenetis dipisahkan dari genus Pichia. Berdasarkan data sekuens dan karakteristik fenotipik maka diusulkan genus baru yaitu Kodamaea. Nama genus Kodamaea digunakan untuk menghormati Dr. Kenkichi Kodama dengan studinya tentang sistematika khamir pada genus Pichia dan genus terkait lainnya. Perbandingan morfologi dan biokimia dari isolat $\mathrm{Ed} 1 \mathrm{~B}$ dengan spesies Kodamaea ohmeri (Pichia ohmeri) ditunjukkan pada Tabel 5.

Isolat khamir Ed 1B merupakan isolat khamir endofit yang berasal dari jus batang tanaman tebu yang telah difermentasi. Isolat ini mampu hidup pada kadar gula tinggi seperti jus tebu. Jus tebu yang telah difermentasi merupakan salah satu sumber terbaik untuk mengisolasi khamir. Menurut Obasi et al. (2017), bahwa populasi khamir dalam produk melibatkan berbagai proses biokimia yang dilakukan oleh khamir untuk memanfaatkan gula sederhana yang ada dalam produk pertanian. Ada sumber yang berbeda untuk isolasi spesies khamir yang sebagian besar dari makanan asam. Di antaranya adalah jus jeruk dan jus tebu yang dianggap sebagai sumber terbaik. Menurut Tikka et al. (2013), bahwa khamir pada umumnya terdapat pada sampel yang 
kaya dengan gula seperti daun, bunga, buah manis, eksudat pohon, dan biji-bijian.

Penemuan spesies $K$. ohmeri telah didukung oleh penelitian sebelumnya yang melaporkan bahwa spesies $K$. ohmeri dapat diisolasi dari beberapa buah dan jus buah yang telah difermentasi diantaranya adalah buah pisang, buah jeruk terfermentasi, coklat terfermentasi dan kopi terfermentasi. Hal ini sesuai dengan pernyataan dari Gana et al. (2014), bahwa khamir yang diisolasi dari permukaan buah pisang salah satunya adalah $K$. ohmeri. Menurut Masoud et al. (2004), bahwa Pichia ohmeri merupakan salah satu khamir dari hasil fermentasi kopi. Menurut Obasi et al. (2014), bahwa Kodamaea ohmeri adalah spesies yang diisolasi dari hasil fermentasi jus jeruk yang sehat. Menurut Koff et al. (2017), bahwa terdapat 11 species yang telah diidentifikasi dari fermentasi coklat, diantaranya yaitu Kodamaea ohmeri.

Studi ini membuktikan bahwa spesies Kodamaea ohmeri telah ditemukan pada jus tebu terfermentasi. Hal ini berbeda dengan penelitian referensi sebelumnya yaitu spesies khamir yang ditemukan dari isolasi jus tebu adalah Saccharomyces cerevisae dan Saccharomyces rouxii. Perbedaan ini bisa disebabkan oleh beberapa hal yaitu cara isolasi, media isolasi, dan tebu yang digunakan. Menurut penelitian yang dilakukan oleh Khattab et al. (2016), bahwa spesies yang ditemukan dari jus tebu adalah Saccharomyces cerevisae. Menurut Rashid et al. (2013), bahwa spesies Saccharomyces cerevisae dan Saccharomyces rouxii telah berhasil diisolasi dari jus tebu terfermentasi.

\section{KESIMPULAN}

Berdasarkan penelitian yang telah dilakukan, maka dapat disimpulkan bahwa telah ditemukan isolat khamir dari batang tanaman tebu. Identifikasi biokimia mampu menseleksi isolat-isolat khamir sehingga didapatkan 1 isolat terpilih $\mathrm{Ed} \mathrm{1B}$. Uji fermentasi karbohidrat pada isolat $\mathrm{Ed} 1 \mathrm{~B}$ menunjukkan bahwa adanya hasil positif pada fermentasi glukosa dan sukrosa, namun tidak memfermentasi laktosa. Uji glukosa $50 \%$ menunjukkan bahwa Isolat Ed1B dapat tumbuh dengan baik pada media glukosa 50\%. Isolat Ed 1B dipilih karena memiliki kemampuan paling cepat dalam memfermentasi glukosa dan sukrosa, serta paling cepat tumbuh pada media glukosa $50 \%$. Identifikasi secara molekuler menunjukkan bahwa isolat Ed 1B merupakan spesies dari Kodamaea ohmeri atau Pichia ohmeri. Kodamaea ohmeri merupakan khamir memiliki peran dalam memfermentasi glukosa dan sukrosa, tumbuh pada tekanan osmotik tinggi, serta memiliki potensi dalam menghasilkan etanol.

\section{DAFTAR PUSTAKA}

Afshan N, Jan M, Hamid M, Nawaz B, Jabeen D, Ashraf A, Alam S (2017) Isolation and characterization of indigenous yeast species from yoghurt and sugarcane juice for production of bio-ethanol. PSM Microbiol 2:9-14

Boyd AR, Gunasekera TS, Attfield PV, Simic K, Vincent SF, Veal DA (2003) A flow-cytometric method for determination of yeast viability and cell number in a brewery. FEMS Yeast Res 3:11-16. doi: 10.1111/j.15671364.2003.tb00133.x

Bubnová M, Zemančíková J, Sychrová H (2014) Osmotolerant yeast species differ in basic physiological parameters and in tolerance of nonosmotic stresses. Yeast 31:309-321. doi: 10.1002/yea.3024

Dharmayanti NLPI (2011) Filogenetika molekuler: Metode taksonomi organisme berdasarkan sejarah evolusi. Wartazoa 21:1-10

Desjardins P, Conklin D (2010) NanoDrop microvolume quantitation of nucleic acids. J Visualized Exp 45:e2565. doi: $10.3791 / 2565$

Ekasari TWD, Retnoningsih A, Widianti T (2012) Analisis keanekaragaman kultivar pisang menggunakan penanda PCR-RFLP pada Internal Transcribed Spacer (ITS) DNA ribosom. J MIPA 35:21-30

Elias I, Lagergren J (2009) Fast neighbor joining. Theor Comput Sci 410:19932000. doi: $10.1016 /$ j.tcs.2008.12.040 Federhen S (2015) Type material in the 
NCBI Taxonomy Database. Nucleic Acids Res 43: D1086-98 doi: 10.1093/nar/gku1127

Gana NHT, Mendoza BC, Monsalud RG (2014) Isolation, screening and characterization of yeasts with amyloytic, lipolytic, and proteolytic activities from the surface of Philippine bananas (Musa spp.). Philippine J Sci 143:81-87

Giri S, Kindo MJ (2015) Evaluation of five phenotypic tests in the identification of candida species. Nat J Lab Med 4:13-18. doi: njlm/2015/13492:2057

Guo C, Zhao C, He P, Lu D, Shen A, Jiang $N$ (2006) Screening and characterization of yeasts for xylitol production 101:1096-104. J Appl Microbiol. doi: 10.1111/j.13652672.2006.02994.x

Hidayat N, Wignyanto, Sumarsih S, Putri, Al (2016) Mikologi Industri. UB Press, Surabaya

Hidayat T, Kusumawaty D, Kusdianti E, Yati DD, Muchtar AA, Mariana D (2008) Analisis filogenetik molekuler pada Phyllanthus niruri L. (Euphorbiaceae) menggunakan urutan basa DNA daerah Internal Transcribed Spacer (ITS). J Matematika dan Sains 13:16-21

Hikmatyar MF, Royani JI, Dasumiati (2015) Isolasi dan amplifikasi DNA keladi tikus (Thyponium Flagelliform) untuk identifikasi keragaman genetik. J Bioteknol Biosains Indones 2:42-48. doi: 10.29122/jbbi.v2i2.507

Intan RMT, Cholil A, Sulistyowati L (2014) Potensi antagonis jamur endofit dan khamir pada tanaman pisang (Musa accumunata) terhadap jamur Mycosphaerella musicola penyebab penyakit bercak kuning sigatoka. J HPT 2:110-118

Isci B, Yildirim HK, Altindisli A (2014) Evaluation of methods for DNA extraction from must and wine. J Inst Brew 120:238-243. doi: 10.1002/jib.129

Jimoh SO, Ado SA, Ameh JB, Whong CM (2012) Osmotolerance and fermentative pattern of brewer's yeast. World J Life Sci Med Res 2:59 Khattab SMR, Hadi AMA, Dahab NFA,
Atta OM (2016) Isolation, characterization, and identification of yeasts associated with foods from Assiut City, Egypt. BMRJ 13:1-10. doi: 10.9734/BMRJ/2016/24170

Koff O, Samagaci L, Goualie B, Niamke S (2017) Diversity of yeasts involved in cocoa fermentation of six major cocoa-producing regions in Ivory Coast. Eur Sci J 13:496-516. doi: 10.19044/esj.2017.v13n30p496

Korabecna M (2003) The variability in the fungal ribosomal DNA (ITS1, ITS2, and 5.8 S rRNA Gene): Its biological meaning and application in medical mycology. Commun Curr Res Educ Top Trends in Appl Microbiol 2:783787

Kurtzman CP, Fell (2011) The yeast a taxonomy study. Biodiversity and Ecophysiology of Yeast. Springerverlag, Berlin

Lamey $\mathrm{P}$, Selemi M, Vandamme AM (2009) The Phylogenetic Handbook:A Practical Approach to Phylogenetic Analysus and Hypothesis Testing. Cambrige University Press, UK

Lasmini T (2016) Isolasi dan identifikasi khamir penghasil asam indol asetat dari rhizosfer anggrek tanah Pecteilis susannae (L.) Rafin. J Ipteks Terapan 9:261-268. doi: 10.22216/jit.2015.v9i4.556

Masoud W, Cesar L B, Jespersen L, Jakobsen M (2004) Yeast involved in fermentation of Coffea arabica in East Africa determined by genotyping and by direct denaturating gradient gel electrophoresis. Yeast 21:549-556. doi: $10.1002 /$ yea.1124

Mycobank (2018) Kodamaea ohmeri. http://www.mycobank.org/BioloMIC S. Diakses 31 Agustus 2018

Obasi BC, Whong CMZ., Ado SA, Abdullahi IO (2014) Isolation and identification of yeast associated with fermented orange juice. Int $\mathrm{J}$ Eng Sci 3:64-69

Obasi BC, Whong CMZ, Ado SA, Abdullahi IO (2017) Leavening ability of some wild yeasts and the mutant species isolated from fermented orange juice in bakery 
product (bread). FUW Trends In Sci

Tech J 2:596-608

Okwulehie, Cyriacus I, Alfred, Kingsley N (2010) Fungi associated with deterioration of sour-sop (Anona muricata. Linn) fruits In Abia State, Nigeria. Afr J Microbiol Res 4:143-146

Purnamasari MI, Prihatna C, Gunawan AW, Suwanto A (2012) Isolasi dan identifikasi secara molekuler Ganoderma spp. yang berasosiasi dengan penyakit busuk pangkal batang di kelapa sawit. J Fitopatologi Indones 8:9-15. doi: 10.14692/jfi.8.1.9

Rada AH, Kasaie Z (2017) A comparative study on different methods for the evaluation of baker's yeast bioactivity. Int J Food Prop 20:100106. doi: 10.1080/10942912.2016.1141297

Rahmansyah, Kanti A (1999) Isolat-isolat khamir dari minuman tradisional laru Di NTT. Berita Biologi 4:255-263. doi:

10.14203/beritabiologi.v4i5.1244

Rashid ANMMO, Dash BK, Chowdhury NA (2013) Exploration of potential baker's yeast from sugarcane juice:Optimation and evaluation. Pak $J$ Biol Sci 16:617-623. doi: 10.3923/pjbs.2013.617.623

Ren A, Ishida A, Akiyama Y (2013) Assessing statistical reliability of phylogenetic trees via a speedy double bootstrap method. Mol Phylogenet Evol 67:429-435. doi: 10.1016/j.ympev.2013.02.011

Santoso, Yahya, Suryaningtyas $\mathrm{NH}$, Rahayu KS (2015) Deteksi mikrofilaria Brugia malayi pada nyamuk Mansonia spp dengan pembedahan dan metode PCR di Kabupaten Tanjung Jabung Timur. Aspirator 7:29-35. doi: 0.22435/aspirator.v7i1.3728.29-35

Sari RMT, Saputro TB, Muhibuddin A (2016) Uji potensi fermentasi etanol yeast tanah yang diisolasi dari metode budidaya SDN di daerah Batu Jawa Timur. J Sains Seni ITS 5:2337-352. doi: 10.12962/j23373520.v5i2.20601

Sharma S, Arora A, Sharma P, Singh S, Nain L, Paul D (2018) Notable mixed substrate fermentation by native Kodamaea ohmeri strains isolated from Lagenaria siceraria flowers and ethanol production on paddy straw hydrolysates. Chem Cent J 12:8. doi: 10.1186/s13065018-0375-8

Stamps JA, Yang LH, Morales VM, Mills KLB (2012) Drosophila regulate yeast density and increase yeast community similarity in a natural substrate. Plos One 7: e42238. doi: 10.1371/journal.pone.0042238

Sumerta IN, Kanti A (2017) Keragaman jenis khamir penghasil etanol yang diisolasi dari makanan fermentasi di kepulauan Riau. J Biol Indones 13:61-69. doi: 10.14203/jbi.v13i1.3096

Supriatna (2008) Melestarikan Alam Indonesia. Yayasan Obor Indonesia, Jakarta

Suryaningsih V, Ferniah RS, Kusdiyantini E (2018) Karakteristik morfologi, biokimia, dan molekuler isolat khamir IK-2 hasil isolasi dari jus buah sirsak (Annona muricata L.). J Akademika Biol 7:18-25

Tam HM, Diep CN (2014) Isolation, characterization and identification of endophytic bacteria in sugarcane (Saccharum spp. L.) cultivated on soils of the Dong Nai province, Southeast of Vietnam. Am J Life Sci 2:361-368 doi: 10.11648/j.ajls.20140206.16

Tesfaw A, Assefa F (2014) Current trends in bioethanol production by Saccharomyces cerevisiae: Substrate, inhibitor reduction, growth variables, coculture and immobilization. International Scholarly Res Notices. doi: 10.1155/2014/532852

Tikka C, Osuru HP, Atluri N, Raghavulu PCV, Yellapu NK, Mannur IS, Prasad UV, Aluru S, Varma N, Bhaskar M (2013) Isolation and characterization of ethanol tolerant yeast strains. Bioinformation 9:421-425. doi: 10.6026/97320630009421

Widiastutik N, Alami NH (2014) Isolasi dan Identifikasi Yeast dari Rhizosfer Rhizopora mucronata Wonorejo. J Sains dan Seni ITS 
3:2337-3520. doi: 10.12962/j23373520.v3i1.5612 Yamada Y, Suzuki T, Matsuda M, Mikata $\mathrm{K}$ (1995) The phylogeny of Yamadazyma ohmeri (Etchells Et Bell) Billon-Grand based on the partial sequences of $18 \mathrm{~S}$ And $26 \mathrm{~S}$ ribosomal RNAs: The proposal of Kodamaea Gen. Nov. (Saccharomycetaceae). Biosci Biotechnol Biochem 59:1172-1174. doi: $10.1271 / \mathrm{bbb} .59 .1172$ 